\title{
The use of selected molecular biology techniques for the detection of Tomato black ring virus in plant sap
}

\author{
Zastosowanie wybranych technik biologii molekularnej \\ do wykrywania wirusa czarnej pierścieniowej plamistości pomidora \\ (Tomato black ring virus) w soku roślinnym
}

\author{
Beata Hasiów-Jaroszewska*, Daria Budzyńska, Natasza Borodynko-Filas, Henryk Pospieszny
}

\begin{abstract}
Summary
Tomato black ring virus (TBRV) infects a wide range of economically important plants, ornamental species and trees. The population of the virus is very diverse and the concentration of particles in plants depends on many factors such as isolate, host and climatic conditions. This causes serious problems in the development of effective and rapid methods to detect genetically diverse isolates. The methods used for the direct detection of the virus in the infected plant material, e.g. immunosorbent assays, do not always give satisfactory results. An immunocapture reverse transcription loop-mediated isothermal amplification (IC-RT-LAMP) and immunocapture real-time reverse transcription polymerase chain reaction (IC-RT-qPCR) protocols were developed for the detection of TBRV in different hosts. Eight isolates from black locus (Robinia pseudoacacia L.), one from tomato (Solanum lycopersicum cultivar Moneymaker) and one from zucchini (Cucurbita pepo convar. giromontiina cultivar Astra Polka) were tested. Both methods enabled sensitive, reproducible and specific detection of TBRV in infected plants.
\end{abstract}

Key words: TBRV; detection; IC-RT-qPCR; IC-RT-LAMP

\section{Streszczenie}

Wirus czarnej pierścieniowej plamistości pomidora (Tomato black ring virus, TBRV) poraża szeroki zakres roślin gospodarczo ważnych, rośliny ozdobne oraz drzewa. Populacja wirusa jest bardzo zróżnicowana, a stężenie cząstek w roślinach zależy od takich czynników, jak: izolat, gospodarz i warunki klimatyczne. Powoduje to istotne problemy w opracowywaniu skutecznych i szybkich metod umożliwiających wykrywanie zróżnicowanych genetycznie izolatów wirusa. Stosowane dotychczas techniki do bezpośredniego wykrywania wirusa w porażonym materiale roślinnym, np. test immunoenzymatyczny ELISA, nie zawsze dawały zadowalające rezultaty. Opracowano warunki łańcuchowej reakcji polimerazy w czasie rzeczywistym (poprzedzonej odwrotną transkrypcją) oraz izotermicznej amplifikacji kwasów nukleinowych w połączeniu z serologicznym zagęszczaniem cząstek wirusa z soku roślinnego. Do badań wykorzystano 8 izolatów z robinii akacjowej (Robinia pseudoacacia L.) oraz jeden z pomidora (Solanum lycopersicum odmiana Moneymaker) i jeden z cukinii (Cucurbita pepo convar. giromontiina odmiana Astra Polka). Obie metody wykrywały wirusa w specyficzny i czuły sposób w zainfekowanych roślinach.

Słowa kluczowe: TBRV; diagnostyka; IC-RT-qPCR; IC-RT-LAMP

Instytut Ochrony Roślin - Państwowy Instytut Badawczy

Zakład Wirusologii i Bakteriologii

Władysława Węgorka 20, 60-318 Poznań

*corresponding author: B.Hasiow@iorpib.poznan.pl 


\section{Wstęp / Introduction}

Wirus czarnej pierścieniowej plamistości pomidora (Tomato black ring virus, TBRV) należy do podgrupy B rodzaju Nepovirus, rodziny Secoviridae (King i wsp. 2012; Hasiów-Jaroszewska i wsp. 2015a). TBRV po raz pierwszy opisano w Anglii, gdzie jego obecność stwierdzono na pomidorze (Smith 1946). Obecnie wirus występuje w Europie (m.in. Finlandia, Niemcy, Norwegia, Włochy), Ameryce Północnej (Kanada, USA), Ameryce Południowej (Brazylia), Azji (Indie, Japonia, Turcja) i Afryce (Kenia) (Sastry 1966; Kaiser i wsp. 1978; Jończyk i wsp. 2004; Yücel i wsp. 2008; Šneideris i wsp. 2012; Rymelska i wsp. 2013). W Polsce TBRV po raz pierwszy wykryto w 1969 roku na pomidorze (Twardowicz-Jakusz 1969). Charakterystyczne dla wirusów z rodzaju Nepovirus jest przenoszenie przez nicienie $\mathrm{z}$ rodzaju Longidorus i Xiphinema (Harrison i wsp. 1961; Harrison 1964; Harrison i Murant 1977). Wirus może być również przenoszony przez nasiona (Lister i Murant 1967).

TBRV poraża szeroki zakres roślin, w tym rośliny gospodarczo ważne, ozdobne oraz drzewa. Występowanie wirusa potwierdzono między innymi na pomidorze, cebuli, ogórku, cukinii, winorośli, truskawce i robinii akacjowej (Borodynko i wsp. 2011). Wirus na porażonych roślinach wywołuje takie objawy, jak chlorotyczne zmiany występujące lokalnie lub systemicznie, niekiedy w postaci charakterystycznych pierścieni, mozaiki, nekrozy, deformacje liści, zahamowanie wzrostu rośliny (Pospieszny i Borodynko 2005). Powszechnym dla nepowirusów zjawiskiem jest tzw. pozorne ozdrowienie - zanik objawów chorobowych w czasie (Giersch 1986).

Materiał genetyczny wirusa stanowią dwie cząsteczki RNA o polaryzacji dodatniej (+ ssRNA): RNA 1 o długości około 7500 nukleotydów (nt) oraz RNA 2 o długości około 4500 nt (Jończyk i wsp. 2004; Digiaro i wsp. 2015). Każda z cząsteczek genomowego RNA upakowana jest w osobny kapsyd. W obrębie rodzaju Nepovirus ze względu na podobieństwo sekwencji, właściwości serologiczne i długość cząsteczki RNA 2, wyróżniono trzy podgrupy: A, B i C (King i wsp. 2012; Digiaro i wsp. 2015). Długość nici RNA 2 w poszczególnych podgrupach wynosi odpowiednio: $3700-4000 \mathrm{nt}, 4400-4700 \mathrm{nt}, 6400-7300 \mathrm{nt}$ (Steinkellner i wsp. 1992). W oparciu o wcześniej wymienione kryteria TBRV zakwalifikowano do podgrupy B. Obie cząsteczki genomowego RNA zawierają na końcu 5' białko VPg, a na końcach 3' dołączony jest ogon poliadenylowy (Rymelska i wsp. 2013). RNA 1 zawiera geny istotne dla replikacji i „dojrzewania” wirusa, natomiast RNA 2 geny białka płaszcza (CP - coat protein) oraz białka transportowego (MP - movement protein). Zarówno w przypadku RNA 1, jak i RNA 2 produktami translacji są poliproteiny, odpowiednio p1 (około $254 \mathrm{kDa}$ ) oraz p2 (około $149 \mathrm{kDa}$ ), które ulegają potranslacyjnemu cięciu na funkcjonalne białka (Steinkellner i wsp. 1992). Oprócz genomowych cząsteczek spotykane jest występowanie małych cząsteczek satelitarnego RNA (sat-RNA) oraz defektywnych RNA (Oncino i wsp. 1995; Jończyk i wsp. 2004; Hasiów-Jaroszewska i wsp. 2012).

Do wykrywania wirusa najczęściej stosowane są: test immunoenzymatyczny ELISA (enzyme-linked immuno- sorbent assay) oraz reakcja odwrotnej transkrypcji sprzężona z łańcuchową reakcją polimerazy (RT-PCR - reverse transcription polymerase chain reaction) (Jończyk i wsp. 2004; Pospieszny i Borodynko 2005; Digiaro i wsp. 2007; Wei i Clover 2008; Rymelska i wsp. 2013). W ostatnich latach opisano również różne warianty łańcuchowej reakcji polimerazy w czasie rzeczywistym (qPCR - quantitative polymerase chain reaction) $\mathrm{z}$ zastosowaniem barwników fluorescencyjnych lub sond molekularnych (Harper i wsp. 2011; Hasiów-Jaroszewska i wsp. 2015a, b). W 2015 roku opisano metodę izotermalnej amplifikacji RNA wirusa (LAMP - loop mediated isothermal amplification), pozwalającą na szybkie wykrywanie genetycznie różnych izolatów w warunkach stałej temperatury (Hasiów-Jaroszewska i wsp. 2015a). Reakcja LAMP przeprowadzana jest przy użyciu polimerazy o aktywności zastępowania nici DNA oraz co najmniej dwóch par starterów: zewnętrznych (outer primers) i wewnętrznych (inner primers) (Almasi i wsp. 2014). Izotermiczne warunki przebiegu reakcji umożliwiają jej przeprowadzenie bez konieczności użycia specjalistycznej aparatury. Wykazano, że reakcja LAMP może być 10-100 razy czulsza $\mathrm{w}$ porównaniu $\mathrm{z}$ konwencjonalną techniką PCR (polymerase chain reaction) (Lee i wsp. 2011; Almasi i wsp. 2014; Hasiów-Jaroszewska i wsp. 2015a).

Dotychczasowe metody stosowane do bezpośredniego wykrywania TBRV w soku roślinnym często nie dawały zadowalających rezultatów ze względu na niską koncentrację cząstek wirusa. Z kolei wcześniej prowadzone badania wykazały, że specyfika składu chemicznego soku roślinnego może inhibować działanie enzymów biorących udział w reakcji RT-PCR powodując uzyskanie wyniku fałszywie negatywnego (Rowhani i wsp. 1995). Znaczącym problemem okazała się też niska wydajność izolacji RNA z materiału roślinnego oraz jakość uzyskanego materiału genetycznego.

Celem pracy było opracowanie skutecznych warunków wykrywania wirusa bezpośrednio w soku roślinnym, bez potrzeby izolacji RNA. Wykorzystano molekularne techniki identyfikacji $\mathrm{w}$ połączeniu $\mathrm{z}$ technikami serologicznymi, tzw. serologiczne opłaszczanie przeciwciałami (IC immunocapture) sprzężone z RT-qPCR (IC-RT-qPCR) lub izotermalną amplifikacją DNA (IC-RT-LAMP) i sprawdzano ich uniwersalność względem różnych gospodarzy.

\section{Materiały i metody / Materials and methods}

\section{Materiał roślinny}

W badaniach wykorzystano 8 izolatów TBRV pochodzących z robinii akacjowej (Robinia pseudoacacia L.) pozyskanych w 2016 roku oraz jeden zebrany z pomidora (Solanum lycopersicum odmiana Moneymaker) (2011) $\mathrm{i}$ jeden $\mathrm{z}$ cukinii (Cucurbita pepo convar. giromontiina odmiana Astra Polka) (2005). Kontrolę negatywną stanowił materiał roślinny wolny od wirusa. Z każdej próbki robinii akacjowej, pomidora i cukinii pobrano po $100 \mathrm{mg}$ tkanki roślinnej. Materiał następnie homogenizowano w $0,5 \mathrm{ml}$ buforu PBS (phosphate buffered saline) $\mathrm{z}$ dodatkiem Tween 20 (PBS-T). Tak przygotowane próbki tes- 
towano na obecność TBRV metodami IC-RT-qPCR oraz IC-RT-LAMP.

\section{Opłaszczanie probówek przeciwciałami}

Reakcja IC-RT-qPCR stanowi połączenie konwencjonalnej techniki RT-qPCR z techniką serologiczną (Ling i wsp. 2007; Pospieszny i wsp. 2012). W pierwszym etapie ma miejsce wyłapywanie i zagęszczanie wirionów występujących w soku roślinnym przez specyficzne przeciwciała. W drugim etapie przeprowadzana jest właściwa reakcja amplifikacji materiału genetycznego wirusa oparta na technikach biologii molekularnej. Probówki do reakcji IC-RT-qPCR i IC-RT-LAMP opłaszczono przeciwciałami TBRV-N1 uzyskanymi w Zakładzie Wirusologii i Bakteriologii Instytutu Ochrony Roślin - Państwowego Instytutu Badawczego (IOR - PIB) w Poznaniu w 2000 roku oraz komercyjnie dostępnymi przeciwciałami IgG TBRV AS0884 (Deutsche Sammlung von Mikroorganismen und Zellkulturen, DSMZ, Niemcy). W celu optymalizacji warunków reakcji przeciwciała rozcieńczono w buforze węglanowym (Loewe Biochemica GmbH, Niemcy) 100, 50 i 25 razy. Przeprowadzono godzinną inkubację w temperaturze $37^{\circ} \mathrm{C}$. Następnie probówki trzykrotnie przepłukano buforem PBS-T oraz naniesiono do nich po $50 \mu \mathrm{l}$ wcześniej przygotowanego ekstraktu roślinnego (badanych prób oraz kontroli negatywnych) i całość inkubowano w temperaturze $37^{\circ} \mathrm{C}$ przez godzinę. Probówki płukano jak wyżej.

\section{RT-qPCR}

Do opłaszczonych probówek dodano $20 \mu 1$ mieszaniny do reakcji RT-qPCR przygotowanej zgodnie z zaleceniami producenta (iTaq ${ }^{\mathrm{TM}}$ Universal SYBR $^{\circledR}$ Green One-Step Kit, Bio-Rad, USA). W skład mieszaniny wchodziło: $10 \mu 1$ iTaq $^{\mathrm{TM}}$ Universal SYBR ${ }^{\circledR}$ Green reaction mix, 0,25 $\mu \mathrm{l}$ odwrotnej transkryptazy iScript, $1 \mu \mathrm{l}$ startera 70R i 70F (10 $\mu \mathrm{M})$ (Harper i wsp. 2011) i 7,75 $\mu$ l wody. Reakcję prowadzono w aparacie LightCycler ${ }^{\circledR} 96$ (Roche, Niemcy) w następujących warunkach termicznych: odwrotna transkrypcja prowadzona przez 10 minut w $50^{\circ} \mathrm{C}$, aktywacja polimerazy i wstępna denaturacja $60 \mathrm{~s} \mathrm{w} 95^{\circ} \mathrm{C}$, 40 cykli amplifikacji (denaturacja $15 \mathrm{~s} \mathrm{w} 95^{\circ} \mathrm{C}$, przyłączanie starterów i wydłużanie nici $60 \mathrm{~s} \mathrm{w} 63^{\circ} \mathrm{C}$ ), chłodzenie $37^{\circ} \mathrm{C}$ przez minutę. Analizę krzywych topnienia przeprowadzono w cyklu: $10 \mathrm{~s} \mathrm{w} 95^{\circ} \mathrm{C}, 60 \mathrm{~s} \mathrm{w} 65^{\circ} \mathrm{C}$ i $1 \mathrm{~s} \mathrm{w} 95^{\circ} \mathrm{C}$.

\section{RT-LAMP}

Do tak przygotowanych probówek opłaszczonych przeciwciałami naniesiono mieszaninę reakcyjną o objętości $25 \mu \mathrm{l}$. W skład mieszaniny wchodziło $15 \mu$ l Isothermal Master Mix ISO-001 (OptiGene, Wielka Brytania), $0,25 \mu \mathrm{l}(1 \mathrm{u} / \mu \mathrm{l})$ odwrotnej transkryptazy (Novazym, Polska), $2 \mu$ l starterów FIB/BIP, 0,5 $\mu$ l starterów F3/B3 (Hasiów-Jaroszewska i wsp. 2015a) i 4,75 $\mu$ l wody. Reakcję IC-RT-LAMP przeprowadzono w dwóch wariantach. W pierwszym przypadku probówki inkubowano przez 30 minut $\mathrm{w}$ temperaturze $63^{\circ} \mathrm{C}$ w bloku grzejnym (Biometra, Niemcy). Wyniki analizowano poprzez rozdział amplikonów w 1,5\% żelu agarozowym z dodatkiem barwnika Midori Green (Nippon Genetics, Japonia). W drugim przypadku reakcję prowadzono przez 30 minut w temperaturze $63^{\circ} \mathrm{C} \mathrm{w}$ aparacie LightCycler ${ }^{\circledR} 96$ (Roche, Niemcy), co umożliwiło analizę powstających krzywych amplifikacji w czasie rzeczywistym.

\section{Czułość testu ELISA oraz reakcji IC-RT-qPCR i IC-RT-LAMP}

W celu określenia czułości testowanych metod wykonano dziesiętne rozcieńczenia soku $\mathrm{z}$ roślin porażonych TBRV $\left(10^{-1}\right.$ do $\left.10^{-9}\right)$ i wykorzystano $\mathrm{w}$ teście ELISA (Clark i Adams 1977) oraz reakcjach IC-RT-qPCR i IC-RT-LAMP zgodnie z metodyką opisaną powyżej.

\section{Wyniki i dyskusja / Results and discussion}

TBRV należy do grupy wirusów, których materiałem genetycznym jest RNA. Wirusy te charakteryzują się dużą zmiennością genetyczną. Zróżnicowanie genetyczne jest mechanizmem ewolucyjnym umożliwiającym przystosowanie się patogena do warunków środowiskowych i zasiedlania nowych nisz ekologicznych (Hasiów-Jaroszewska i Pospieszny 2008). W ostatnich latach stosunkowo liczne występowanie TBRV w Polsce zaobserwowano przede wszystkim w uprawie roślin dyniowatych (Borodynko i wsp. 2011). W warunkach naturalnych TBRV jest także patogenem roślin dziko rosnących i drzew wieloletnich, w tym robinii akacjowej i bzu czarnego. Odmienna zawartość związków chemicznych w różnych gatunkach roślin oraz ich morfologia wpływają na efektywność detekcji wirusa poszczególnymi metodami diagnostycznymi. W przypadku materiału roślinnego pochodzącego z robinii akacjowej czy pomidora, wykrywanie wirusa techniką ELISA lub RT-PCR okazało się mało skuteczne i często otrzymywano wynik negatywny, pomimo obecności wirusa w badanych próbach. Wpływ na to mogła mieć niska koncentracja wirusa lub/i niska wydajność izolacji RNA wirusa i jakość uzyskanego materiału genetycznego.

Celem przeprowadzonych badań było opracowanie skutecznych technik do bezpośredniego wykrywania wirusa $\mathrm{w}$ materiale roślinnym. Opracowano warunki dla zastosowania dwóch technik: IC-RT-qPCR oraz IC-RTLAMP z wykorzystaniem różnych przeciwciał; pozyskanych w Zakładzie Wirusologii i Bakteriologii IOR - PIB (TBRV-N1) oraz dostępnych komercyjnie przeciwciał TBRVAS-0884. W celu optymalizacji reakcji probówki opłaszczono przeciwciałami o różnych rozcieńczeniach. Najefektywniejszy przebieg reakcji zaobserwowano przy zastosowaniu przeciwciał rozcieńczonych 50 razy. Wynik reakcji IC-RT-LAMP przebiegającej w bloku grzejnym wizualizowano w 1,5\% żelu agarozowym. W próbach, w których użyto ekstrakt $\mathrm{z}$ chorych roślin obserwowano typowe dla reakcji LAMP drabinowe ułożenie prążków (rys. 1a). Analiza krzywych amplifikacji reakcji prowadzonych w aparacie LightCycler ${ }^{\circledR} 96$ potwierdziła obecność wirusa $\mathrm{w}$ testowanych próbach, zarówno w przypadku IC-RT-LAMP, jak i IC-RT-qPCR (rys. 1b, 2a). Obecność specyficznego produktu reakcji IC-RT-qPCR potwierdzono poprzez analizę krzywych topnienia. Temperatura topnienia dla produktów reakcji IC-RT-qPCR wyniosła 


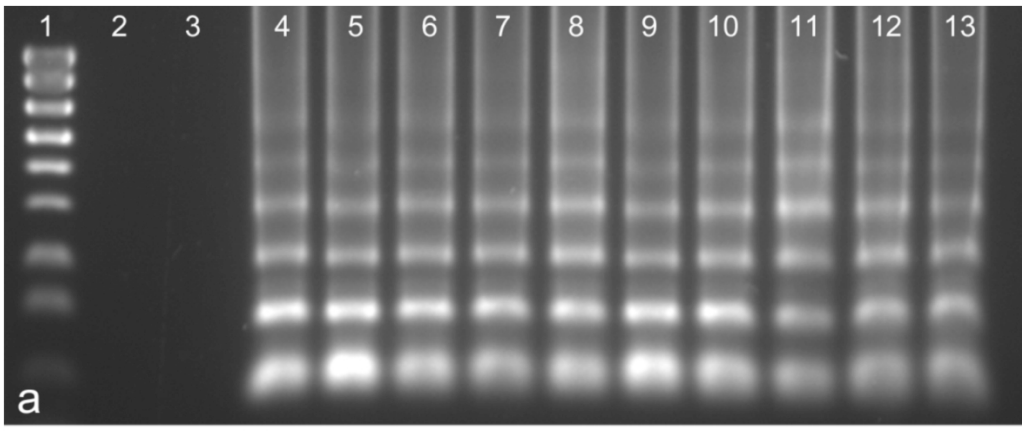

b

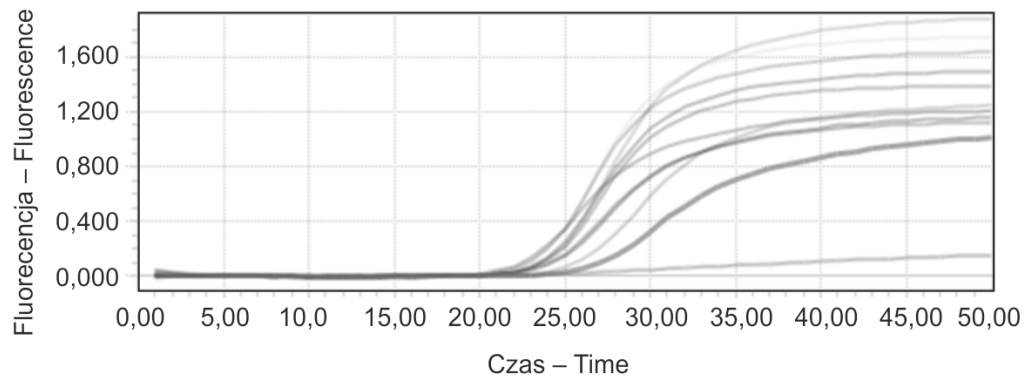

Rys. 1. Wykrywanie izolatów TBRV za pomocą reakcji IC-RT-LAMP. a) analiza produktów reakcji w żelu agarozowym: 1 - marker wielkości DNA HyperLadder IV (Bioline, Wielka Brytania); 2, 3 - kontrole negatywne, próbki ze zdrowego pomidora i cukinii, 4-13 - badane próbki TBRV, b) krzywe amplifikacji powstałe w wyniku reakcji RT-LAMP w aparacie LightCycler ${ }^{\mathbb{B}} 96$ (Roche)

Fig. 1. Detection of TBRV isolates by IC-RT-LAMP. a) analysis of reaction products on agarose gel: 1 - DNA weight marker HyperLadder IV (Bioline, UK); 2, 3 - negative controls, samples from healthy zucchini and tomato plants, 4-13 - analyzed samples of TBRV, b) amplification curves obtained in RT-LAMP in $\operatorname{LightCycler}^{\circledR} 96$ (Roche)

\section{a}
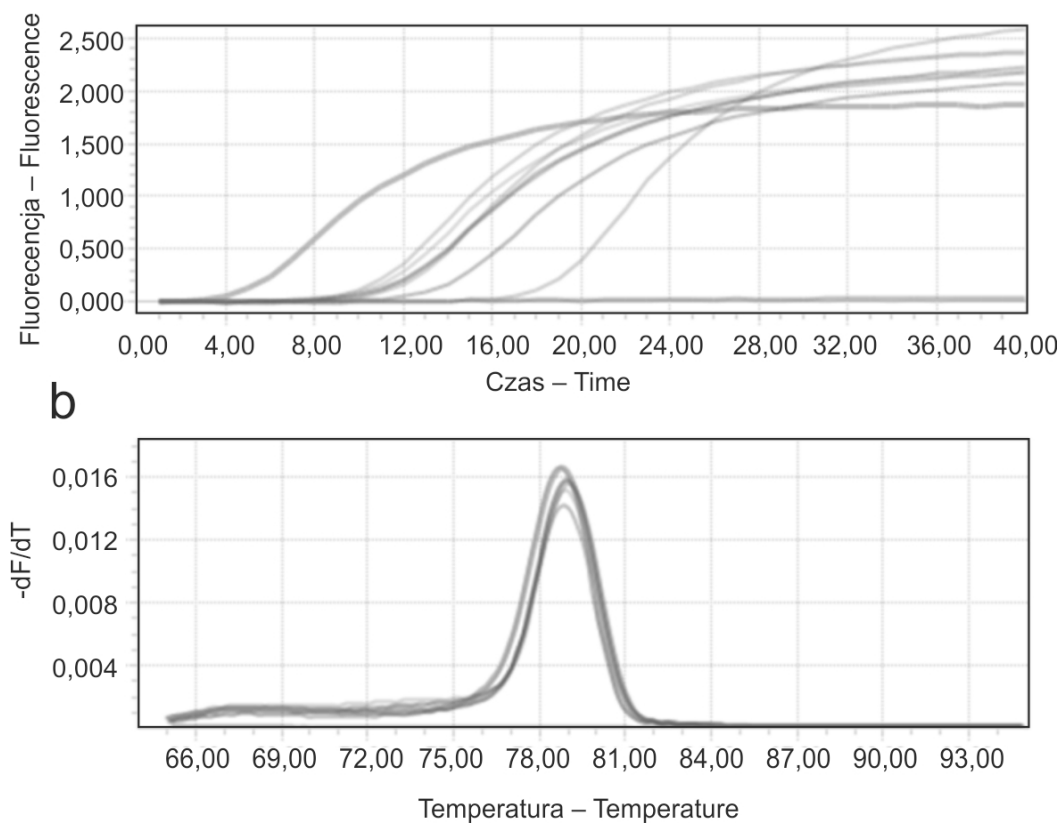

Rys. 2. Wykrywanie izolatów TBRV za pomocą reakcji IC-RT-qPCR. a) krzywe amplifikacji powstałe w wyniku reakcji IC-RT-qPCR w aparacie LightCycler ${ }^{\circledR} 96$ (Roche), b) krzywe topnienia produktów reakcji IC-RT-qPCR w aparacie LightCycler $^{\circledR} 96$ (Roche)

Fig. 2. Detection of TBRV isolates by IC-RT-qPCR. a) amplification curves obtained in IC-RT-qPCR reaction in LightCycler ${ }^{\mathbb{B}} 96$ (Roche), b) melting curves of IC-RT-qPCR products obtained in LightCycler ${ }^{\circledR} 96$ (Roche)

około $79^{\circ} \mathrm{C}$ (rys. 2b). W mieszaninach, gdzie użyto ekstrakt zdrowych roślin, stanowiących kontrole negatywne, nie zaobserwowano zajścia reakcji. Czas przebiegu reakcji RT-LAMP był o połowę krótszy niż reakcji RT-qPCR.
W przypadku obu metod możliwe było wykrycie TBRV stosując $10^{-8}$ rozcieńczenie soku $\mathrm{z}$ porażonych roślin, natomiast w teście ELISA tylko $10^{-3}$. 
Zarówno reakcja IC-RT-qPCR, jak i IC-RT-LAMP są przydatnymi narzędziami diagnostycznymi. Przeciwciała skierowane przeciwko TBRV umożliwiły efektywne wyłapanie i zagęszczanie cząstek wirusa $\mathrm{z}$ ekstraktu roślinnego i przez to ominięcie etapu izolacji RNA. Reakcję IC-RT-qPCR stosowano wcześniej do wykrycia wirusa pasiastej mozaiki jęczmienia (Barley stripe mosaic virus, BSMV) (Zarzyńska i wsp. 2014). Wykazano, że technika ta pozwala na wykrycie wirusa $\mathrm{w}$ próbach, które w teście ELISA oznaczono jako negatywne. Technikę wykorzystano również do wykrywania wirusa mozaiki tytoniu (Tobacco mosaic virus, TMV) oraz wirusa odglebowej mozaiki pszenicy (Soil-borne wheat mosaic virus, SBWMV) z gleby (Yang i wsp. 2012; Trzmiel i Lewandowska 2015). Przewagą technik IC-RT-qPCR oraz IC-RT-LAMP nad powszechnie stosowanym testem ELISA jest drugi, molekularny etap reakcji, zwiększający jej czułość i specyficzność. Połączenie metody serologicznej $\mathrm{z}$ molekularną $\mathrm{z}$ powodzeniem może być stosowane w wykrywaniu wirusa w próbach o jego niskiej koncentracji. Dodatkowo do przebiegu reakcji IC-RT-LAMP nie jest wymagane zastosowanie specjalistycznej, drogiej aparatury laboratoryjnej. Stała temperatura reakcji pozwala na zastosowanie urządzeń typu łaźnia wodna. Wyniki reakcji mogą być analizowane za pomocą rozdziału elektroforetycznego oraz w świetle UV, po dodaniu odpowiednich barwników łączących się z DNA. Zastosowanie specjalistycznego sprzętu umożliwia $\mathrm{z}$ kolei monito- rowanie przebiegu reakcji w czasie rzeczywistym i analizę powstałych krzywych amplifikacji i topnienia. Technika IC-RT-LAMP znalazła zastosowanie do wykrywania między innymi wirusa brązowej plamistości pomidora (Tomato spotted wilt virus, TSWV), wirusa liściozwoju ziemniaka (Potato leafroll virus, PLRV), wirusa kędzierzawki wierzchołkowej buraka (Beet curly top virus, BCTV) i Banana bract mosaic virus (BBrMV) (Fukuta i wsp. 2004; Almasi i wsp. 2012, 2014; Zhang i wsp. 2016).

Obie techniki z powodzeniem mogą być wykorzystane do bezpośredniego wykrywania TBRV w soku roślinnym. Zaletą technik jest to, że w trakcie jednego testu można przebadać do 90 prób. Mogą one również znaleźć zastosowanie w badaniach materiału nasiennego.

\section{Wnioski / Conclusions}

Techniki IC-RT-qPCR i IC-RT-LAMP z powodzeniem można wykorzystać do wykrywania TBRV w różnych gatunkach roślin, szczególnie w przypadku występowania wirusa w niskiej koncentracji.

Badania zostały częściowo sfinansowane ze środków przyznanych przez Narodowe Centrum Nauki w projektach 2013/11/B/NZ9/02510 i 2015/17/B/NZ8/02407.

\section{Literatura / References}

Almasi M.A., Hosseyni-Dehabadi S.M., Aghapour-Ojaghkandi M. 2014. Comparison and evaluation of three diagnostic methods for detection of Beet curly top virus in sugar beet using different visualizing systems. Applied Biochemistry and Biotechnology 173 (7): $1836-1848$

Almasi M.A., Moradi A., Nasiri J., Karami S., Nasiri M. 2012. Assessment of performance ability of three diagnostic methods for detection of Potato leafroll virus (PLRV) using different visualizing systems. Applied Biochemistry and Biotechnology 168 (4): $770-784$.

Borodynko N., Hasiów-Jaroszewska B., Rymelska N., Pospieszny H. 2011. Występowanie wirusa czarnej pierścieniowej plamistości pomidora (Tomato black ring virus) w Polsce. [Occurrence of Tomato black ring virus in Poland]. Progress in Plant Protection/Posteppy w Ochronie Roślin 51 (4): 1603-1611.

Clark M.F., Adams A.N. 1977. Characterization of the microplate method of enzyme-linked immunosorbent assay for detection of plant viruses. Journal of General Virology 34 (3): 475-483.

Digiaro M., Elbeaino T., Martelli G.P. 2007. Development of degenerate and species-specific primers for the differential and simultaneous RT-PCR detection of grapevine-infecting nepoviruses of subgroups A, B and C. Journal of Virological Methods 141 (1): 34-40.

Digiaro M., Yahyaoui E., Martelli G.P., Elbeaino T. 2015. The sequencing of the complete genome of a Tomato black ring virus (TBRV) and of the RNA2 of three Grapevine chrome mosaic virus (GCMV) isolates from grapevine reveals the possible recombinant origin of GCMV. Virus Genes 50 (1): 165-171.

Fukuta S., Ohishi K., Yoshida K., Mizukami Y., Ishida A., Kanbe M. 2004. Development of immunocapture reverse transcription loopmediated isothermal amplification for the detection of Tomato spotted wilt virus from chrysanthemum. Journal of Virological Methods 121 (1): 49-55.

Giersch T. 1986. Studies on the concentration and distribution of virus in TRSV infected tobacco plants (N. tabacum cv. Xanthi-nc). Mededelingen van de Faculteit Landbouwwetenschappen Rijksuuniversiteit Gent 51: 855-863.

Harper S.J., Delmiglio C., Ward L.I., Clover G. 2011. Detection of Tomato black ring virus by real-time one-step RT-PCR. Journal of Virological Methods 171 (1): 190-194.

Harrison B.D. 1964. Specific nematode vectors for serologically distinctive forms of Raspberry ringspot and Tomato black ring viruses. Virology 22 (4): 544-550.

Harrison B.D., Mowat W.P., Taylor C.E. 1961. Transmission of a strain of Tomato black ring virus by Longidorus elongatus (Nematoda). Virology 14 (4): 480-485.

Harrison B.D., Murant A.F. 1977. Nematode transmissibility of pseudo-recombinant isolates of tomato black ring viruses. Annals of Applied Biology 86 (2): 209-212.

Hasiów-Jaroszewska B., Borodynko N., Figlerowicz M., Pospieszny H. 2012. Two types of defective RNAs arising from the Tomato black ring virus genome. Archives of Virology 157 (3): 568-572.

Hasiów-Jaroszewska B., Budzyńska D., Borodynko N., Pospieszny H. 2015a. Rapid detection of genetically diverse Tomato black ring 
virus isolates using Reverse Transcription Loop-Mediated Isothermal Amplification. Archives of Virology 160 (12): $3075-3078$.

Hasiów-Jaroszewska B., Pospieszny H. 2008. Zmienność genetyczna RNA wirusów w aspekcie ich diagnostyki i właściwości biologicznych. Na pograniczu chemii i biologii. Tom XX. Wydawnictwo Naukowe UAM w Poznaniu: 27-40.

Hasiów-Jaroszewska B., Rymelska N., Borodynko N. 2015b. LNA probe-based assay for the detection of Tomato black ring virus isolates. Molecular and Cellular Probes 29 (1): 78-80.

Jończyk M., Le Gall O., Pałucha A., Borodynko N., Pospieszny H. 2004. Cloning and sequencing of full-length cDNAs of RNA1 and RNA2 of a Tomato black ring virus isolate from Poland. Archives of Virology 149 (4): 799-807.

Kaiser W.J., Bock K.R., Guthrie E.J., Meredith G. 1978. Occurrence of tomato black ring virus in potato cultivar in Kenya. Plant Disease Reporter 62 (12): 1088-1092.

King A., Adams M., Carstens E., Lefkowitz E. 2012. Family Secoviridae. Classification and Nomenclature of Viruses. Ninth Report of the International Committee of Taxonomy of Viruses. Virus Taxonomy: 881-889.

Lee M., Lin Y., Lai G., Lai S., Chen H., Wang M. 2011. One-step reverse-transcription loop-mediated isothermal amplification for detection of infectious bursal disease virus. Canadian Journal of Veterinary Research $=$ Revue canadienne de recherche vétérinaire 75 (2): 122-127.

Ling K., Wechter W.P., Jordan R. 2007. Development of a one-step immunocapture real-time TaqMan RT-PCR assay for the broad spectrum detection of Pepino mosaic virus. Journal of Virological Methods 144 (12): 65-72.

Lister R.M., Murant A.F. 1967. Seed-transmission of nematode-borne viruses. Annals of Applied Biology 59 (1): 49-62.

Oncino C., Hemmer O., Fritsch C. 1995. Specificity in the association of Tomato black ring virus satellite RNA with helper virus. Virology 213 (1): 87-96.

Pospieszny H., Borodynko N. 2005. First report of Tomato black ring virus (TBRV) in the natural infection of zucchini. Journal of Plant Protection Research 45 (4): 321-325.

Pospieszny H., Hasiów-Jaroszewska B., Rymelska N., Borodynko N. 2012. Zastosowanie techniki IC real-time RT-PCR do wykrywania wirusa nekrozy pomidora (ToTV) w siewkach z porażonych nasion. [Using the IC real-time RT-PCR technique for the detection of Tomato torrado virus (ToTV) in tomato seedling from infected seeds]. Progress in Plant Protection/Postępy w Ochronie Roślin 52 (3): 515-517.

Rowhani A., Maningas M.A., Lile L.S., Daubert S.D., Golino D.A. 1995. Development of a detection system for viruses of woody plants based on PCR analysis of immobilized virions. Phytopathology 85: 347-352.

Rymelska N., Borodynko N., Pospieszny H., Hasiów-Jaroszewska B. 2013. Analysis of the biological and molecular variability of the Polish isolates of Tomato black ring virus (TBRV). Virus Genes 47 (2): 338-346.

Sastry K.S.M. 1966. Occurrence of Tomato black ring virus in India. Indian Journal of Microbiology 6: 23-26.

Smith K.M. 1946. Tomato black-ring: a new virus disease. Parasitology 37: 126-130.

Steinkellner H., Himmler G., Sagl R., Mattanovich D., Katinger H. 1992. Amino-acid sequence comparison of nepovirus coat proteins. Virus Genes 6 (2): 197-202.

Šneideris D., Zitikaitė I., Žižytė M., Grigaliūnaitė B., Staniulis J. 2012. Identification of nepoviruses in tomato (Lycopersicon esculentum Mill.). Zemdirbyste Agriculture 99 (2): 173-178.

Trzmiel K., Lewandowska M. 2015. Detection and discrimination of European isolates of Soil-borne wheat mosaic virus using immunocapture real-time reverse transcription-polymerase chain reaction. Journal of Virological Methods 225: 55-58.

Twardowicz-Jakusz A. 1969. Badania diagnostyczne nad czarną pierścieniową plamistością pomidora. Biuletyn Instytutu Ochrony Roślin 44: 123-136.

Wei T., Clover G. 2008. Use of primers with 50 non-complementary sequences in RT-PCR for the detection of nepovirus subgroups A and B. Journal of Virological Methods 153 (1): 16-21.

Yang J.-G., Wang F.-L., Chen D.-X., Shen L.-L., Qian Y.-M., Liang Z.-Y., Zhou W.-C., Yan T.-H. 2012. Development of a one-step immunocapture real-time RT-PCR assay for detection of Tobacco mosaic virus in soil. Sensors 12 (12): 16685-16694.

Yücel S., Canan C., Melike Y., Raziye C., Yesim A. 2008. Tomato pathology in Turkey. The European Journal of Plant Science and Biotechnology 2 (1): 38-47.

Zarzyńska A., Jeżewska M., Trzmiel K., Hasiów-Jaroszewska B. 2014. Development of a one-step immunocapture real-time RT-PCR assay for the detection of Barley stripe mosaic virus strains in barley seedlings. Acta Virologica 58 (1): 81-85.

Zhang J., Borth W., Lin B., Dey K., Melzer M., Shen H., Pu X., Sun D., Hu J. 2016. Deep sequencing of banana bract mosaic virus from flowering ginger (Alpinia purpurata) and development of an immunocapture RT-LAMP detection assay. Archives of Virology 161 (7): 1783-1795. 